\title{
FUTURE OF SEMICONDUCTOR FABRICATION (FAB) INDUSTRIES IN INDIA- OPPORTUNITIES AND CHALLENGES
}

\author{
Himanshu Kushwah ${ }^{1}$, Anil Sethi ${ }^{2}$ \\ ${ }^{1}$ Assistant Professor, Department of Electronics, Keshav Mahavidyalaya, University of Delhi, Delhi, India \\ ${ }^{2}$ Assistant Professor, Department of Electronics, Keshav Mahavidyalaya, University of Delhi, Delhi, India
}

\begin{abstract}
The peak demand of electronics products in India will reach several billions in forthcoming years. It has been always a dream of Electronics engineers in India to have a well structured manufacturing sector. At present a good number of companies are working in design but they don't have their own fabrication facility here. The design projects which they are handling have larger dependency on foreign FABs. The country is a leading exporter of information technology service, including knowledge-intensive chip design under the EDA environment. India's strength in chip design doesn't help at all as we are lacking in wafer fabrication. Local electronics manufacturing remains disconnected from India's chip design capabilities, research and development area. This has also affect the employment of electronics engineer as we have lacking in electronics manufacturing. India's increasing domestic demand of electronics products results in rise in imports of final products and high dependency on key components/ICs. The manufacturing of semiconductor in India will only boost up with effective and growth oriented semiconductor policy and with a well maintained eco-system set up by the central government so that international player may attract to set up the wafer fabrication and $R \& D$ units in India.
\end{abstract}

Keywords: FAB, ESDM, NPE, EDA, Wafer.

\section{INTRODUCTION}

The Integrated Circuit (IC) devices play very crucial role in modern society of electronics system design, from industrial applications such as computer controlled application and operated machinery to mechtronics, microwave telecommunication, and daily computing needs. In today's world we can't think for a single minute with out semiconductor chips embedded gadgets in our day-to-day life by making it pleasurable, smooth, safer and healthier. Semiconductor designer today shrink the size of transistor on wafer such that they have little distance to travel, which increase the processing of data tremendously. Unfortunately the Indian semiconductor industry is at a low stage. Most of the existing players in this industry are focused on fabless chip design and there are no semiconductor players with capabilities in semiconductor fabrication (fab.) or in 'ecosystem' manufacturing. The current Semiconductor Policy is expected to create incentives for players to invest in semiconductor fabrication under Make in India initiatives recently launched by the Government of India. This policy provides the path for development of both FAB and ecosystems unit. (Description given below):

\subsection{Electronic Design Unit (EDU)}

Design Units includes the facility of semiconductor chip design under electronic design automation environment. It doesn't involve actual fabrication or packaging of semiconductors wafers. The hardware circuit design is first simulated and after certain design rule checks it's ready for test manufacturing. India has its master hand in design units through many international players which have already setup their base here. ${ }^{[4]}$

\subsection{Eco-System Unit (ESU)}

The Eco-System Unit comprises a developed and matured corridor of Original Design Manufacturer (ODM)/ Original Equipment Manufacturer (OEM) to fulfill the need of home State. The ODM/ OEM are the manufacturers of semiconductor displays such as LED, LCD, OLED, Plasma display and other advanced displays. They also manufacture memory devices, solar cells and nano technology products. [4]

\subsection{Fabrication Unit (FAB)}

The fabrication unit includes semiconductor wafer fabrication facility, ATMP (Assembly Test Mark Pack) and the quality cross check mechanism. The input for this unit is from design units ${ }^{[4]}$.

\section{$A$ Visual of FAB Unit}

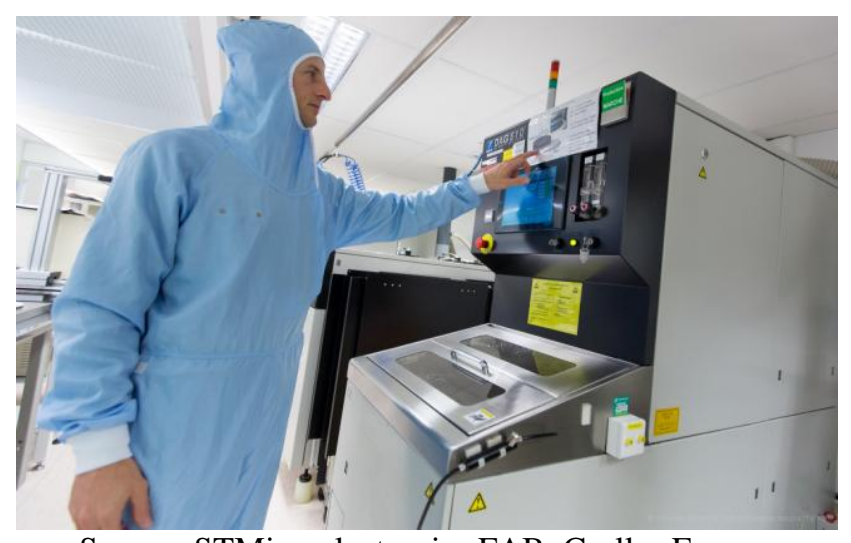

Source: STMicroelectronics FAB, Crolles France. 


\section{OPPORTUNITIES FOR TALENT}

A well structured manufacturing sector will open ample amount of opportunities for engineering graduates in the form of direct and indirect job profile. Engineering graduates from premier institution will get opportunities to work in fabrication sector. Currently they have job profile of design engineer although they have learned design methodologies in their course curriculum.

\section{CURRENT GLOBAL SEMICONDUCTOR INDUSTRY REVIEW}

The current global semiconductor industry scenario is decided by individual market input.

\subsection{Data Processing Market Scenario}

India has always been a supplier of good software design which attracts so many investors here. India is also a leader in data processing market which also attracts significant investment.

\subsection{Consumer Electronics Market}

The electronics products like LED TV, LCD TV and Blue ray players are also the basis of effective revenue generation although they have very low margins. These products have a good inline consumption of semiconductor materials.

\subsection{Automotive Industry}

The growth of semiconductor content per automobile has increased in automobile industry as automobile manufacturers are designing smart vehicle applications. The industry has a good number of international clients for automotive integrated design. Moreover as automotive is a vast industry it will always be a valuable partner.

\subsection{Communication Industry}

A sudden growth in cell phone and laptop market also has a good impact on semiconductor manufacturing. The host companies are looking for experienced chip designer and FABs. The complexity of the chip design has also increased as mobile and electronics gadgets companies want to offer new and advanced features in their products.

\subsection{Industrial Consumption}

Energy-efficient technology and environment friendly technology such as smart grids, smart meters is the key segments.
End Consumption, Global Semiconductor Market, 2009.

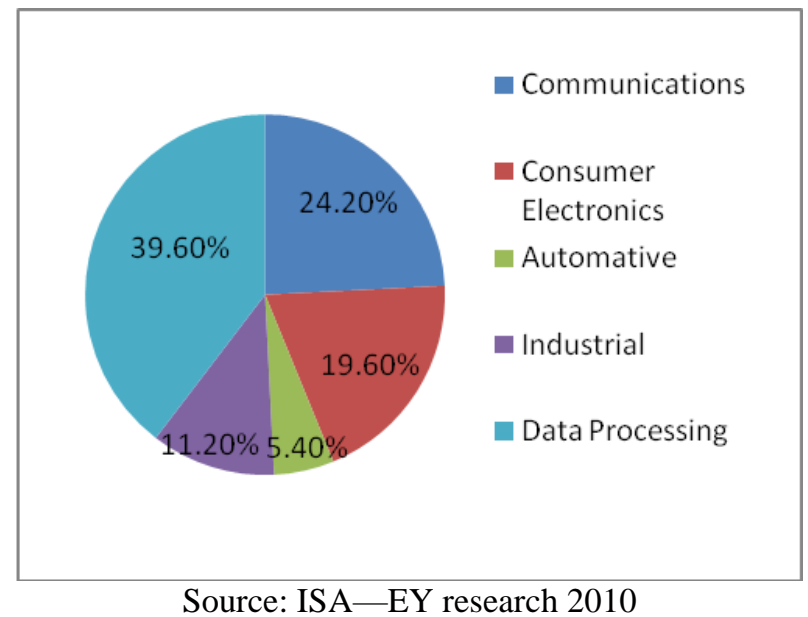

\section{IMPACT OF SEMICONDUCTOR/ WAFER DESIGN INDUSTRIES ON INDIA}

There is no doubt to list that the semiconductor/wafer design industry has contributed positively to our economy. In addition to boosting economy it has also influenced the life of its people through its various socio-eco effects such as employment, education and diversity.
* Contribution to the nation economy.
* Generation of Direct/Indirect employment platform.
* Foreign Exchange Earnings through export.
* Bridging the gender divide, as approx. $20 \%$ of the workforce consisting of women.
* A large investment in R\&D Sector.

\section{Geographical Spilt of Semiconductor Market, 2009}

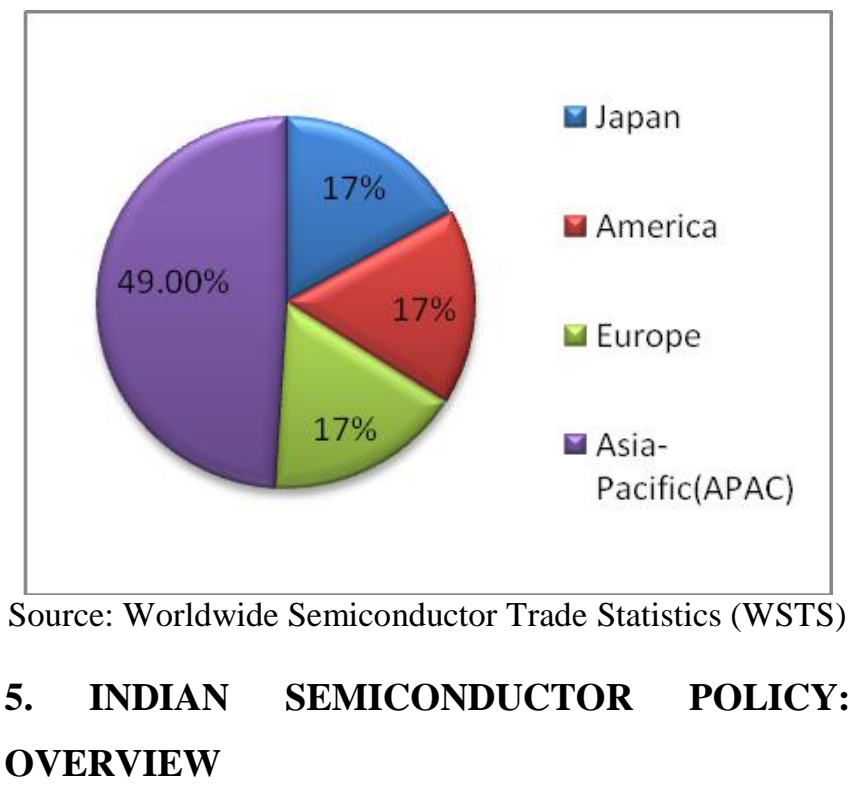

The Policy aims to develop Analog Semiconductor Fabrication , Micro and Nano Manufacturing technology as vibrant industry for inclusive growth and creating direct and indirect employment opportunities for the people of the 
state. The Policy should be growth oriented so as to create a sustainable system, and must be lucrative to fetch good amount of investment. ${ }^{[3]}$

\subsection{Objectives}

* To increase the flow of investments in the State towards making India and the State self sufficient in Electronics wafer manufacturing.

* To maximize the direct and indirect employment opportunities for the young engineers in the State.

* To promote establishment of FAB units in the State. ${ }^{[3]}$

\subsection{Strategy}

* Providing land for establishment of FAB units in the States.

* Host State will provide art of infrastructure confirming to the international standards for the FAB units.

* Facilitating transportation of raw material and other goods efficiently by providing transport, warehousing and allied infra.

* Facilitating housing and related social infra for the employees of the FAB units.

* Making available power, water etc. at par rates available to FAB units internationally.

\subsection{Overview}

Semiconductor manufacturing policy announced in February 2007: ${ }^{[4]}$

* $20 \%$ subsidy for the first ten years for SEZ Units.

* $25 \%$ subsidy for the first ten years for a non- SEZ Units.

* Exemption form CVD for both fabrication and ecosystem manufacturing for non-SEZ units.

* Investments:

$>$ FAB Unit : INR 25,000 Cr.

$>$ Eco-System Unit : INR $1000 \mathrm{Cr}$.

\section{SEMICONDUCTOR/ WAFER DESIGN} INDUSTRY KEY DRIVERS \& CHALLENGES

\subsection{Key Drivers Factor}

\section{(i) Easy Availability of Good Talent Pool}

As the Indian Government trying to focus on how to improve easy access to higher education and increasing number of central universities and colleges throughout the nation, which will produce a large number of tech-students, pool every year to fulfill the need of industries. Moreover the government recently launched Skill India, Make in India and Digital India Schemes which will automatically generate technical capabilities among the youth. ${ }^{[8]}$

\section{(ii) Cost Competitiveness Factor}

Cost Competitions is one of the important parameters in Semiconductor Design Industry. Although the cost structures are gradually increasing, but India still has an overall advantage as compared to other nation such as U.S or Japan. One of the main reasons is low labor cost as well.

\section{(iii) Reverse Brain Drain towards home State}

The sustainable growth, infrastructure and lucrative pay package in home State will attract the talented pool already employed in foreign countries for earnings in these sectors. So this will try to fix the problem of VLSI engineers draining from home state and generate opportunities to learn more about their heritage as well.

\section{(iv) Enjoying Geographic Advantage}

The Semiconductor Design companies in India are enjoying the vicinity advantage with APAC (Asia Pacific) Customer in comparison to US or Japan, as they are near to us in terms of distance and we are sync to their time zone as well. So these companies are flooded with quality design work.

\section{(v) Experienced in Design Methodologies}

The Semiconductor Design companies in India gained a considerable amount of experience in chip design as compared to slow design earlier. So these companies are getting many chip design projects as compared to other new players in the markets. The Complexity of the chip design is also increasing as the technology is merging more towards nano technology end.

\subsection{Challenges}

\section{(i) Effective Semiconductor Policy for State}

The Government of India should frame an effective and growth oriented Semiconductor Policy for State, which will attract potential and experienced wafer manufacturers at this level. This may also include a one transparent clearance window system by the government for companies.

\section{(ii) Lack of Semiconductor Manufacturing}

\section{Ecosystem}

* The several electronic appliances companies have insufficient experience in the field of electronic parts manufacturing. We don't have active manufacturing corridor for ecosystem. Unless this gap is bridged, the ecosystem can't become active.

* The lack of Original Design Manufacturer or Original Equipments Manufacturer companies that can manage the in-house demand of electronics products.

\section{(iii) Human Resource Linked Challenges}

(a) Quality of engineering grads. available

* Fresh Engineers: The lack of collaboration between industries and Education institutions creates a pivotal problem at the very first step. The course curriculum is not designed at par to fulfill the needs of industries. This gap results in lack of required skills among engineering graduates. This implies higher training 
cost and longer period before a fresh engineer becomes productive for company. The situation is worsened when a trained engineer leaves a company for a lucrative package.

* Lack of technical experience: Companies are facing lack of experience in terms of in-depth knowledge of design methodologies.

* Ease in Digital Design: India has strong capabilities in digital and software technologies, but it still lacks conceptually strong engineering graduates who can achieve same level of ease in analog design.

\section{(b) Lack of valuation to technical people}

In India, more value is given to management people in comparison to technical sound people. This is exasperated by salary differences between technical and management staff with same length of experience.

\section{(iv) Competition with Taiwan, China and Other}

\section{Countries in manufacturing and e-design}

These countries have already developed a grown ecosystem, which has developed over the last 35 years, with the structured base of Original Equipments Manufacturer/ Original Design Manufacturer companies, strong Government support, effective Policies to avoid insecurity of investments, world-class infrastructure, uninterrupted power supplies etc. Due to these factors these countries attract investors even in the field of design activities. ${ }^{[2]}$

\section{CONCLUSION}

India has emerged as the World's third largest market for electronic products. The demand of electronic goods has crossed all the limits. Smart phone and computer market has seen tremendous growth over the last twenty years. However, India has been unable to scale up its production to meet this peak demand. The Government of India has recently approved setting up of two Semiconductor Wafer Fabrication Manufacturing facilities in India with the help of two business consortia. As far as seeds of manufacturing are concerned this step is a motivational factor towards Indian industry roadmap to become a semiconductor manufacturing hub. Recently India Electronics and Semiconductor Association (IESA) sign a MoU with Singapore Semiconductor Industry Association to set up and develop trade and technical association between both the countries. Both Singapore and Indian markets are considered important markets in the global EDSM sector and companies from both the countries are looking to set up manufacturing units (FAB) here. Along with Government support \& effective policies we will create a favorable environment for all the investors and technological partner. A robust electronics manufacturing sector in India will bring positive hike in our economy and will put India at the forefront of electronics manufacturing.

\section{REFERENCES}

[1]. Zhongwen, G., 'Innovation in China's Electronic Information Industry', China Communications, Hong Kong, June 2006.

[2]. Price water house Coopers (2013), Continuing to Grow: China's Impact on Semiconductor Industry -- 2013 Update, Technology Institute, New York, 2013

[3]. Analog Semiconductor Fabrication (FAB) Investment Policy-2015, February, 2014, Deptt. Of Science \& Technology, MP.

[4]. Tata Strategic management group,"Indian Semiconductor Industry: Evolution \& Oppertunities", $K$. Raman, K. Ganguli.

[5]. Zhao, Z., Huang, X., Ye, D. \& Gentle, P. (2007), "China's Industrial Policy in Relation to Electronics Manufacturin", China and World Economy, Vol. 15, Issue 3, pp. 33-51.

[6]. "Two Ex TI-ers Invest \$1B in India's First Analog Fab"EE Times News Report,Febryary,2015.(Input from: Approval to establish two Semiconductor wafer manufacturing companies in India, PIB,GOI, Feb 2015) .

[7]. "An Introduction to Electronic System Packaging,wafer fabrication, inspection \& testing Module 2", Deptt. Of Electronic System Engineering, IISc Bangalore, Mahesh G.V. 